\title{
In Vitro Cytotoxic and Anti-inflammatory Activities of Tanacetum argenteum (Lam.) Willd. subsp. argenteum Extract
}

\section{Tanacetum argenteum subsp. argenteum Ekstrelerinin In Vitro Sitotoksik ve Anti-inflamatuvar Etkileri}

\author{
Gökay ALBAYRAK¹, Ayșe NALBANTSOY², Șüra BAYKAN* \\ 'Ege University, Faculty of Pharmacy, Department of Pharmaceutical Botany, İzmir, Turkey \\ ${ }^{2}$ Ege University, Faculty of Engineering, Department of Bioengineering, İzmir, Turkey
}

\begin{abstract}
Objectives: The objective of this study was to examine the anti-inflammatory and cytotoxic potential of n-hexane, ethyl acetate, and methanolic extracts of Tanacetum argenteum subsp. argenteum.

Materials and Methods: Tanacetum L. is the third largest genus of Asteraceae family and is represented by 60 taxa in Turkish flora. Sesquiterpene lactones and pyrethrins are the main chemical groups of the genus. T. argenteum subsp. argenteum is an endemic taxa that is distributed in the Central and South Anatolia.

Results: In vitro anti-inflammatory activity was assayed using iNOS and NF-кB inhibition tests on RAW264.7 and HeLa cells. The cytotoxic activities were tested against ten cell lines using MTT assays.

Conclusion: As a result, the $\mathrm{n}$-hexane extract was found more active than the positive control parthenolide in iNOS test $\left(\mathrm{IC} \mathrm{C}_{50}: 0.627 \pm 0.16 \mu \mathrm{g} / \mathrm{mL}\right)$ and cytotoxic experiments against PC3 and MPANC-96 cell lines ( $\mathrm{IC}_{50}: 2.85 \pm 0.51 \mu \mathrm{g} / \mathrm{mL}$ and $5.35 \pm 1.24 \mu \mathrm{g} / \mathrm{mL}$, respectively).

Key words: Tanacetum argenteum subsp. argenteum, anti-inflammatory, NF-kB, iNOS, cytotoxicity, MTT
\end{abstract}

öz

Amaç: Tanacetum argenteum subsp. argenteum bitkisinin hekzan, etil asetat ve metanol ekstrelerinin anti-inflamatuvar ve sitotoksik potansiyellerini incelemektir.

Gereç ve Yöntemler: Tanacetum L. Asteraceae familyasının en büyük 3. cinsidir ve Türkiye florasında 60 taksonla temsil edilir. Seskiterpen laktonlar ve piretrinler cinsin ana kimyasal gruplarıdır. T. argenteum subsp. argenteum l̇ç ve Güney Anadolu'da yayılış gösteren endemik bir taksondur.

Bulgular: In vitro anti-inflamatuvar aktivite iNOS ve NF-KB inhibisyon metodlarıyla RAW264.7 ve HeLa hücrelerine karşı test edilmiştir. Sitotoksik aktivite MTT metoduyla 10 hücre hattına karșı denenmiştir.

Sonuç: Sonuç olarak, $\mathrm{n}$ hekzan ekstresi iNOS testinde $\left(\mathrm{IC}_{50}: 0.627 \pm 0.16 \mu \mathrm{g} / \mathrm{mL}\right)$ ve PC3 ve MPANC-96 hücreleri $\left(\mathrm{IC}_{50}: 2.85 \pm 0.51 \mu \mathrm{g} / \mathrm{mL}\right.$ ve $5.35 \pm 1.24$ $\mu \mathrm{g} / \mathrm{mL}$, sırasıyla) üzerinde yapılan sitotoksik ölçümlerde pozitif kontrol partenolitten daha etkili bulunmuştur.

Anahtar kelimeler: Tanacetum argenteum subsp. argenteum, anti-inflamatuvar, NF-кB, iNOS, sitotoksisite, MTT

\section{INTRODUCTION}

The genus Tanacetum L. consists of around 160 species in the world ${ }^{1}$ and 60 taxa of the genus exist in Turkey, 26 of which are endemic. ${ }^{2}$ The genus is distributed in Europe and West Asia and all over Turkey, excluding the Aegean side. ${ }^{3,4}$ Tanacetum sp. are used as insecticides, tonic, appetizers, anthelmintics, diuretics, carminatives, stimulants, emmenagogues, antipyretics, and antimigraine agents in Turkey. ${ }^{5}$ Tanacetum parthenium (L.) Schultz Bip. (feverfew) is the most prominent species. It is known as having antimigraine properties and is used to relieve menstrual pain in traditional medicine, and standardized capsules of leaf extract are available on the market. 3,6 Eudesmane sesquiterpenes are the main components of the genus. Tanacetum argenteum. (Lam.) Willd., subsp. argenteum is an endemic perennial plant 
with 20-30 cm stem length and deeply divided or 2-pinnatisect leaves. The involucre is $3-4(-5) \mathrm{mm}$ broad and campanulate. Its flowers are yellow, female flowers are absent, and achenes are brown, 2-2.25 mm. It grows on rocks and limestone cliffs, ranging from 990 to $2500 \mathrm{~m}$. The plant is mainly distributed in Inner and South Anatolia. ${ }^{4}$ The main chemical constituents of $T$. argenteum subsp. argenteum are sesquiterpenoids and flavonoids. Phytochemical studies on this species also resulted with the isolation of $\beta$-sitosterol and $\beta$-amyrin, desacetyllaurenobiolide, spiciformin, tatridin- $A$, tatridin- $B$, desacetyl- $\beta$-cylclopyrethrosin, desacetyltulipinolide-1 $\beta, 10 \alpha-$ epoxide and $8 \alpha$-angeloyloxycostunolide. ${ }^{7}$ Sesquiterpenoids are thought to be the bioactive constituents of this taxon. ${ }^{3}$ The major compounds of the essential oil of the plant are reported as monoterpenes; $\alpha$-pinene, $\beta$-pinene and santolinatriene by previous studies. ${ }^{7-9}$ Caryophyllene oxide and $\alpha$-thujone were found as the main constituents of the oil of $T$. argenteum subsp. canum var. canum in Gören and Tahtasakal ${ }^{10}$ study.

Recently, Orhan et al."1 measured parthenolide levels using liquid chromatograph-mass spectrometry and total flavonoid contents of three subspecies of $T$. argentum. Among all $T$. argenteum subsp. argenteum has the highest parthenolide and total flavonoid contents. The authors also investigated the cholinesterase inhibitory potential of these plants. Among them, the leaf extract of $T$. argenteum subsp. flabellifolium has the strongest cholinesterase inhibitor activity." Gören and Tahtasakal ${ }^{10}$ isolated guaian-type sesquiterpene lactones from $T$. argenteum subsp. canum var. canum and T. argenteum subsp. Flabellifolium. ${ }^{12,13}$

The aim of this study was to investigate the anti-inflammatory and the cytotoxic activity of $n$-hexane, ethyl acetate, and methanolic extracts of $T$. argenteum subsp. argenteum. For this purpose, nuclear factor kappa B (NF-kB) and induced nitric oxide synthesis (iNOS) methods were used as antiinflammatory assays and MTT(3-(4,5-dimethylthiazol-2-yl)2,5-diphenyltetrazolium bromide) was used for cytotoxic activity. Thin-layer chromatography (TLC) analysis of extracts were also performed to obtain an overview on the chemical compounds of the extract.

\section{EXPERIMENTAL}

\section{Plant material}

Plants were collected from Nemrut Mountain, 1600 m, Kahta, Adıyaman on May 30 3012 , 2012 and identified by Şüra Baykan. Voucher specimens have been deposited in the Ege University Herbarium, Faculty of Pharmacy, İzmir, Turkey (IZEF 6029) (www.izef.ege.edu.tr).

\section{Extraction}

Dried and powdered plant parts $(250 \mathrm{~g})$ were extracted sequentially with $n$-hexane, ethyl acetate and methanol (2x300 $\mathrm{mL}$ for each), sonicated at room temperature for $6 \mathrm{~h}$, and then filtered. The combined extracts were evaporated using a rotary evaporator to dryness at $40^{\circ} \mathrm{C}$.

\section{Thin-layer chromatography analysis}

TLC analysis of $n$-hexane, EtOAc, and methanolic extracts of the plant was made. A silica gel-coated aluminum plate was used as the stationary phase and $n$-hexane:ethyl acetate (5:5) solvent system was used as the mobile phase. Comparisons was performed using parthenolide as the reference compound.

\section{Cells}

All cells were obtained from American Type Culture Collection (ATCC, Rockville, MD).

\section{Chemicals and other materials}

MTT, $n$-hexane, parthenolide, Griess reagent, $100 \mu / m L$ penicillin G sodium, $100 \mu / \mathrm{mL}$ streptomycin were from Sigma (St. Louis, MO); ethyl acetate and methanol were from Merck, Germany; RPMI 1640, fetal bovine serum (FBS), 1\% L-glutamine and $1 \%$ gentamicin were obtained from PAA Laboratories $\mathrm{GmbH}$, Cölbe, Germany; DMEM/F12 and RPMI-1640 were from Invitrogen (Carlsbad, CA); $1 \mathrm{mM}$ calcium and magnesium were from Packard Instrument Company (Meriden, CT); bovine calf serum and FBS were from Atlanta Biologicals (Lawrenceville, GA); and the Luciferase Assay Kit was obtained from Promega (E1500).

\section{Assay for in vitro cytotoxicity}

$n$-hexane, EtOAc, and $\mathrm{MeOH}$ extracts of $T$. argenteum subsp. argenteum were tested against ten cell lines using MTT assays. These cell lines included A549 (human alveolar epithelial cells), CaCo-2 (human epithelial colorectal adenocarcinoma), MCF-7 (human breast adenocarcinoma), MPANC-96 (human pancreatic cancer), MDA-MB-231 (metastatic human breast cancer), 253J-BV (bladder cancer cells), U87-MG (human glioblastoma-astrocytoma, epithelial-like), prostate cancer $\left(\mathrm{PC}_{3}\right)$, human cervical carcinoma (HeLa) as cancerous cells and human embryonic kidney (HEK)-293 as noncancerous cells. Parthenolide was used as a positive control. Cells were cultivated in DMEM-F12 medium, passaged twice a week. Cells ( $10^{4}$ cells/well) were seeded to the wells of 96 -well plates and cultivated for $24 \mathrm{~h}$ in an incubator. Extracts with different dilutions $(0.5,5,50 \mu \mathrm{g} / \mathrm{mL})$ and the positive control were added and cells were incubated for $48 \mathrm{~h}$. After $48 \mathrm{~h}$, the number of viable cells was determined using an MTT assay. For this purpose; in order to count the number of living cells, $25 \mu \mathrm{L}$ MTT (stock solution of $2.5 \mathrm{mg} / \mathrm{mL}$ ) physiologic saline $(9 \% \mathrm{NaCl}$ ) was added to the wells and incubated for $4 \mathrm{~h}$. After a while, the medium was removed to dissolve the formazan crystals; $150 \mu \mathrm{L}$ DMSO was added and the absorbance was read at 520 and 620 $\mathrm{nm}$. All measurements were performed in triplets and the halfmaximum inhibitory concentration $\left(\mathrm{IC}_{50}\right)$ was determined using GraphPad Prism 5.

\section{Assay for the inhibition of $N F-\kappa B$ activity}

The NF-кB Luciferase Reporter HeLa Stable Cell Line (Signosis, CA) was used for this assay. Cells were cultured in DMEM-F12 supplemented with $10 \%$ FBS, $100 \mathrm{U} / \mathrm{mL}$ penicillin $\mathrm{G}$ sodium and $100 \mu \mathrm{g} / \mathrm{mL}$ streptomycin at $37^{\circ} \mathrm{C}$ in an atmosphere of $5 \% \mathrm{CO}_{2}$ and $95 \%$ humidity.

Cells $\left(5 \times 10^{5}\right.$ cells/well/90 $\left.\mu \mathrm{L}\right)$ were added to 96 -well plates and incubated for $24 \mathrm{~h}$. Then, test samples at different concentrations $(0.5,5,50 \mu \mathrm{g} / \mathrm{mL})$ were added to the medium and incubated for $30 \mathrm{~min}$. After that, cells were induced with PMA (70 ng/ 
$\mathrm{mL}$ ) for $24 \mathrm{~h}$, and the medium then was removed and the cells were washed with $200 \mu \mathrm{L}$ PBS. Cells were incubated with $20 \mu \mathrm{L}$ lysis buffer on a shaker at room temperature for $1 \mathrm{~h}$. Absorbance was measured using a luminometer subsequent to adding $20 \mu \mathrm{L}$ Luciferase substrate. Parthenolide was used as a positive control.

\section{Assay for inhibition of iNOS activity}

The mouse macrophage (RAW264.7) cells cultured in phenol red-free RPMI medium with $10 \%$ bovine calf serum and $100 \mathrm{U} /$ $\mathrm{mL}$ penicillin $\mathrm{G}$ sodium and $100 \mu \mathrm{g} / \mathrm{mL}$ streptomycin. Cells $\left(10^{5}\right.$ cells/well) were seeded in 96-well plates and incubated for 24 h. Test samples at different concentrations $(0.5,5,50 \mu \mathrm{g} / \mathrm{mL})$ were prepared from $10 \mathrm{mg} / \mathrm{mL}$ stock solution and $20 \mu \mathrm{L}$ were added for each.

After $60 \mu \mathrm{L}$ serum-free medium were added and $30 \mathrm{~min}$ of incubation, LPS $(5 \mu \mathrm{g} / \mathrm{mL})$ was added to the cells to induce iNOS and cells were incubated for $24 \mathrm{~h}$. The concentration of nitric oxide produced as a result of iNOS activity was determined by measuring the level of nitrite in the cell culture supernatant using Griess reagent. The absorbance was read at 540-630 $\mathrm{nm}$. IC $\mathrm{C}_{50}$ values were obtained from dose curves. Parthenolide was used as a positive control and DMSO was used in the tests as a vehicle control. ${ }^{14}$ Extracts were also evaluated using MTT analyses to detect cytotoxic activity against RAW264.7 cells, in addition to the iNOS inhibition test.

\section{RESULTS AND DISCUSSION}

Parthenolide was detected in $n$-hexane and EtOAc extracts of the plant. $R_{F}$ values of $n$-hexane and EtOAc extracts and parthenolide were 0.69 and their distances from origin of all three spots were equal and all three spots were blue. Based on this results, it was concluded that the major compound of $n$-hexane and EtOAc extracts of $T$. argenteum subsp. argenteum was parthenolide. The TLC result is also given as Figure 1.

The results of the cytotoxic activity tests are shown in Table 1. Among the extracts, significant cytotoxic activity of the $n$-hexane extract was observed against CaCo-2, MPANC-96, HEK-293, MDA-MB-231, and $\mathrm{PC}_{3}\left(\mathrm{IC}_{50}\right.$ values of $3.959 \pm 0.62,5.353 \pm 1.24$, $1.651 \pm 0.43,4.154 \pm 0.18,2.847 \pm 0.51 \mu \mathrm{g} / \mathrm{mL}$, respectively). Our results showed that the $n$-hexane extract is more effective than parthenolide against MPANC-96 and $\mathrm{PC}_{3}$. It also had cytotoxic activity as strong as parthenolide against CaCo-2, HEK-293, MDA-MB-231. The viability percentage of $n$-hexane extract is shown in Figure 2. Microscopy images of the cells are shown in Figure 3.

In many studies, cytotoxic activities of various Tanacetum species have been reported. Rateb et al. $^{15}$ found that hydroalcoholic and aqueous extracts of different parts of $T$. parthenium L. had cytotoxic effects. The alcoholic extracts of the flowers of the plant showed significant cytotoxic effects (15\% cell viability) with $50 \mu \mathrm{g} / \mathrm{mL}$ concentration on Ehrlich ascites carcinoma. This activity is considered as a result of synergy of flavonoid and sesquiterpene lactone contents. Rosselli et al. ${ }^{16}$ investigated the cytotoxic activity of eudesmanolides isolated from flowers of Tanacetum vulgare subsp. siculum against an A549 cell line.
This is the first report to demonstrate the cytotoxic activity of $T$. argenteum subsp. argenteum against $\mathrm{CaCo}-2$, MPANC-96, MDAMB-231, 253J-BV, U87-MG, and $\mathrm{PC}_{3}$ cell lines. In a previous report, the plant was analyzed for its cytotoxic property on MCF7 , the cell viability inhibition value of methanolic extract was found as $52.58 \%$ at a concentration of $100 \mu \mathrm{g} / \mathrm{mL}$, whereas we found no serious activity with $\mathrm{MeOH}$ extracts. The difference is likely due to the extraction methods. ${ }^{17}$

Recently, Şen et al. ${ }^{18}$ investigated the cytotoxic activity of aerial parts of $T$. argenteum subsp. argentum against four cell lines [A549, HeLa, HT-29 (human colorectal adenocarcinoma), MCF-7] using MTT assays. The authors found that an $n$-hexane extract of the plant inhibited growth of A-549 and HT-29 cells, and a chloroform extract of the plant inhibited growth of A-549 and HeLa cells at the concentrations of $30 \mu \mathrm{g} / \mathrm{mL}$. Both extracts of the plant inhibited more than $50 \%$ proliferation of cells. When compared their results with ours on the same cell lines; the stronger results observed in our study with the same extracts are likely associated with the quantitative superiority of secondary metabolites responsible for the cytotoxic activity. Thus, the disparity between the two studies could be attributed to the different localities of the plant materials.

Apolar sesquiterpene lactones with $\gamma$ lactone moiety pass into the $n$-hexane fraction could be responsible of the effect because sesquiterpene lactones have a broad spectrum of biologic activities including anti-inflammatory and cytotoxic properties. The lactone ring and exocyclic methylene group of sesquiterpene lactones are considered to be the liable units for biologic activities of sesquiterpenoids. ${ }^{3}$

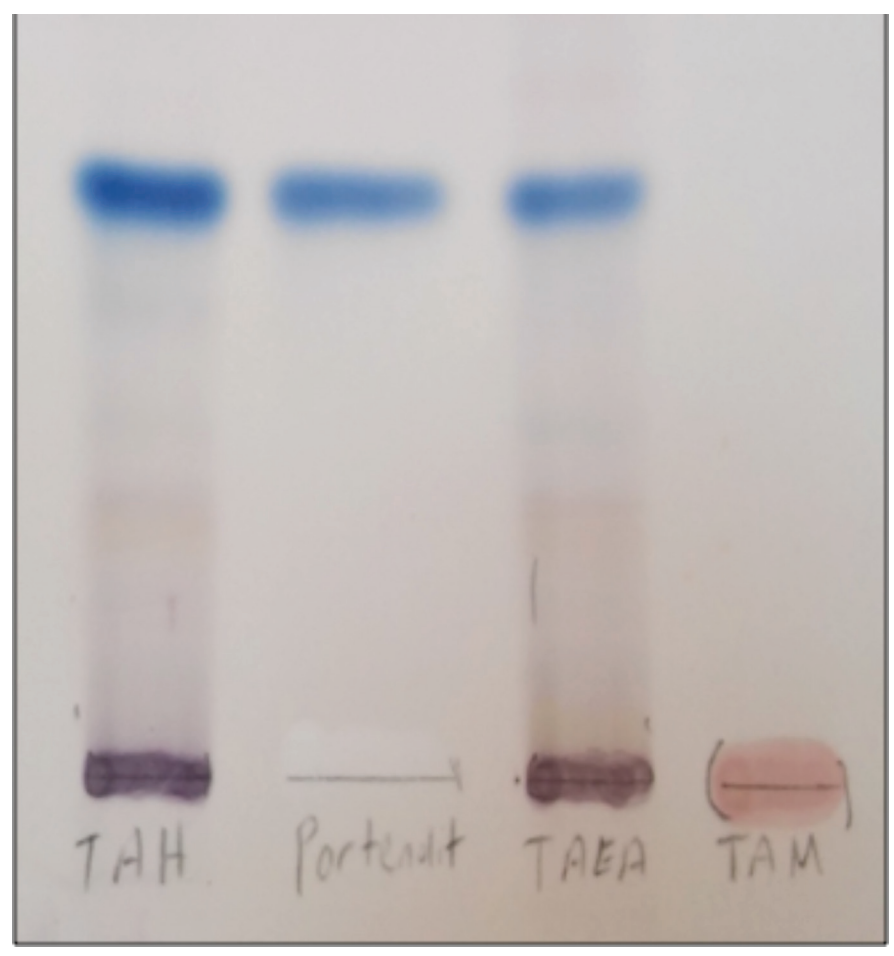

Figure 1. TLC results of parthenolide and $n$-hexane (TAH), EtOAc (TAEA), Methanolic (TAM) extracts of $T$. argenteum subsp. argenteum. Mobile phase system: hexane:ethyl acetate $(5: 5)$ 
It is known that parthenolide, a germacranolide-type sesquiterpene lactone, plays a significant role for antiinflammatory and cytotoxic activities. ${ }^{19}$ Notably T. parthenium, T. vulgare, Tanacetum densum subsp. amani, T. argenteum subsp. Flabellifolium, and T. argenteum subsp. canum var. canum contain parthenolide. ${ }^{3}$ The activities of the $n$-hexane extract and the ethyl acetate extract may be associated with the plant's major component parthenolide.

The anti-inflammatory activity of T. argenteum subsp. argenteum was evaluated using NF-KB and iNOS methods. As the results can be seen in Table 2, n-hexane extract had significant antiinflammatory activity with an $\mathrm{IC}_{50}$ of $6.159 \pm 0.45 \mu \mathrm{g} / \mathrm{mL}$ for NF$\kappa \mathrm{B}$, and $0.627 \pm 0.16 \mu \mathrm{g} / \mathrm{mL}$ for iNOS methods, respectively. Anti-inflammatory activities of various Tanacetum species using in vitro and in vivo methods have been reported. ${ }^{20,21}$ The anti-inflammatory activities of Tanacetum spp. are related to their flavonoid and sesquiterpene contents. In a previous report, Nasri et al. ${ }^{22}$ investigated the hydroalcoholic extract of Tanacetum balsamita and found anti-inflammatory activity related to quercetin, a flavonoid, and we found the antiinflammatory activity of the plant through apolar fractions related to sesquiterpene lactones, most probably parthenolide. Bukhari et al. ${ }^{23}$ noted that the $n$-hexane extract of Tanacetum artemisioides showed stronger in vivo anti-inflammatory activity than that of polar aqueous fractions.

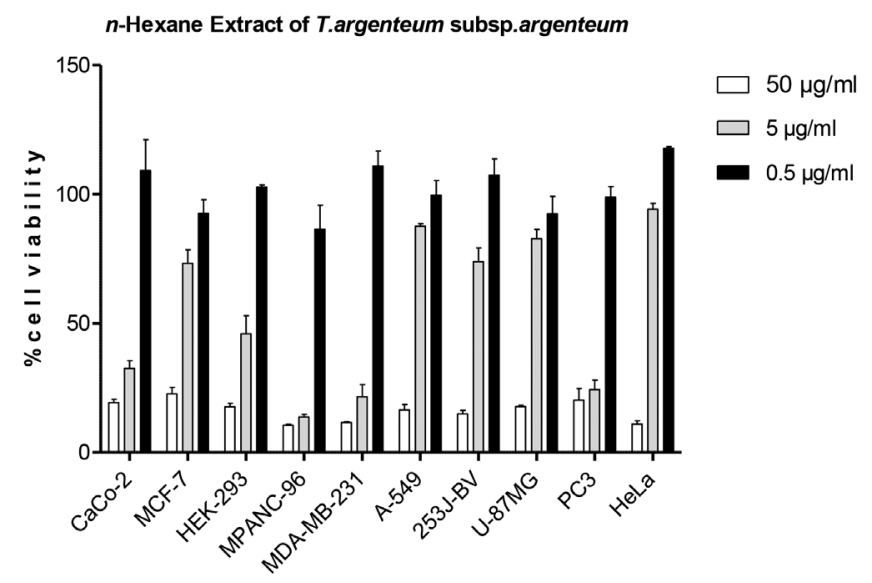

Figure 2. Cell viability of $n$-hexane extract with different concentrations of T. argenteum subsp. argenteum on ten cells
As postulated, sesquiterpene lactones are generally known to

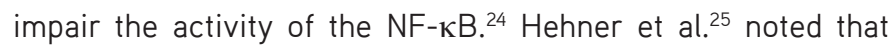
parthenolide, the main compound of $T$. parthenium, is a wellknown anti-inflammatory agent that inhibits the NF-KB pathway. López-Franco et al. $^{26}$ showed parthenolide's inhibiting role using the NF-KB method against murine cells. The $n$-hexane extract is more effective than parthenolide in iNOS methods, whereas parthenolide is stronger than $n$-hexane extracts with $\mathrm{NF}-\kappa \mathrm{B}$. The $n$-hexane extract's potency could be related to a synergistic effect of different secondary metabolites of the extract. The results can also be seen in Figure 4 and 5.

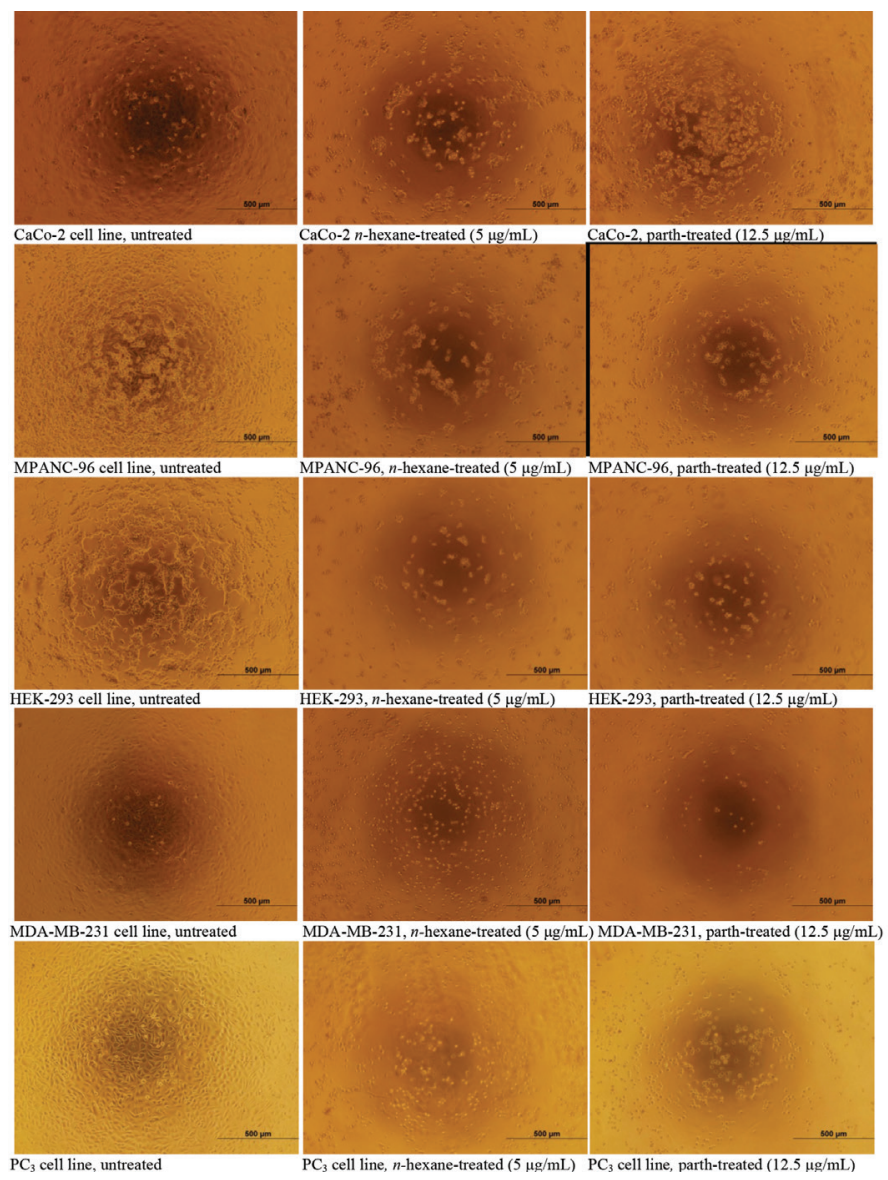

Figure 3. Views of CaCo-2, MPANC-96, HEK-293, MDA-MB-231 and $\mathrm{PC}_{3}$ cells under a microscope $(500 \mu \mathrm{m})$. Untreated cells, hexane and parthenolide treated cells

Table 1. $\mathrm{IC}_{50}$ values for cytotoxic activities of various extracts of Tanacetum argenteum subsp. argenteum extracts on different cells, $\mu \mathrm{g} / \mathrm{mL}$

\begin{tabular}{lllllllllll} 
Extract & A549 & CaCo-2 & MCF-7 & $\begin{array}{l}\text { MPANC- } \\
96\end{array}$ & HEK-293 & $\begin{array}{l}\text { MDA-MB } \\
231\end{array}$ & 253J-BV & U-87 MG & PC & HeLa \\
\hline$n$-hexane & $17.65 \pm 1.52$ & $3.96 \pm 0.62$ & $13.99 \pm 2.61$ & $5.35 \pm 1.24$ & $1.65 \pm 0.43$ & $4.15 \pm 0.18$ & $12.02 \pm 1.19$ & $15.85 \pm 1.54$ & $2.85 \pm 0.51$ & $18.94 \pm 1.00$ \\
\hline EtOAC & $29.24 \pm 5.88$ & $37.54 \pm 10.69$ & $38.16 \pm 5.10$ & $25.66 \pm 3.08$ & $7.39 \pm 0.77$ & $16.21 \pm 2.58$ & $36.19 \pm 10.39$ & - & $18.99 \pm 1.53$ & $21.48 \pm 4.91$ \\
\hline MeOH & - & - & - & - & - & - & - & - & - \\
\hline $\begin{array}{l}\text { Partheno- } \\
\text { lide }\end{array}$ & $3.26 \pm 2.49$ & $3.16 \pm 2.93$ & $7.37 \pm 0.16$ & $5.51 \pm 5.71$ & $1.16 \pm 0.09$ & $3.61 \pm 3.34$ & $6.35 \pm 0.20$ & $3.38 \pm 1.97$ & $3.44 \pm 0.36$ & $5.79 \pm 0.00$ \\
\hline
\end{tabular}


Table 2. $I_{50}$ values for anti-inflammatory activities of various extracts of Tanacetum argenteum subsp. argenteum

\begin{tabular}{lll} 
Extract & iNOS (Raw 264.7) $\mathrm{IC}_{50}(\mu \mathrm{g} / \mathrm{mL})$ with SD & NF- $\mathrm{KB}(\mathrm{HeLa}) \mathrm{IC}_{50}(\mu \mathrm{g} / \mathrm{mL})$ with SD \\
\hline$n$-hexane & $0.627 \pm 0.16$ & $6.159 \pm 0.45$ \\
\hline EtOAC & $1.602 \pm 0.48$ & $37.505 \pm 1.51$ \\
\hline $\mathrm{MeOH}$ & $17.15 \pm 1.65$ & - \\
\hline Parthenolide & $0.674 \pm 0.01$ & $1.779 \pm 0.14$ \\
\hline
\end{tabular}

-: No activity, SD: Standard deviation

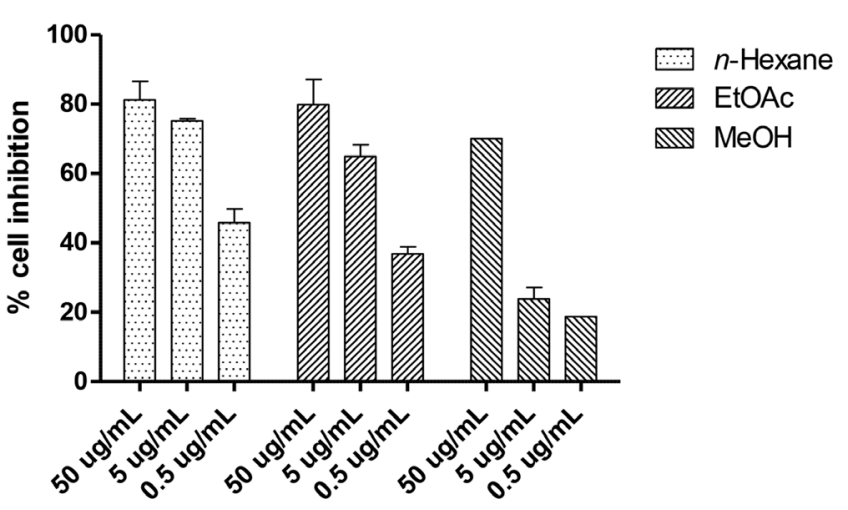

Figure 4. Various extracts of $T$. argenteum subsp. argenteum with different concentrations HeLa cell line, NF-KB method

\section{CONCLUSION}

Our results indicated that the $n$-hexane extract of $T$. argenteum subsp. argenteum has promising cytotoxic activity on $\mathrm{CaCo}-2$, MPANC-96, HEK-293, MDA-MB-231, and PC 3 cells, and also anti-inflammatory activity. Parthenolide, a well-known antiinflammatory and cytotoxic agent was detected in $n$-hexane and EtOAc extracts of the plant using TLC analysis. $n$-hexane extract's activity may be associated with its major component parthenolide and other substances in the plant. Phytochemical experiments are ongoing with $n$-hexane extracts of $T$. argenteum subsp. argenteum.

Conflict of Interest: No conflict of interest was declared by the authors.

\section{REFERENCES}

1. Orhan IE, Tosun F, Gulpinar AR, Kartal M, Duran A, Mihoglugil F, Akalgan D. LC-MS quantification of parthenolide and cholinesterase inhibitory potential of selected Tanacetum L. (Emend. Briq.) taxa. Phytochemistry Letters. 2015;11:347-352.

2. Güner A, Aslan S, Ekim T, Vural M, Babaç M. Türkiye bitkileri listesi (damarlı bitkiler). Nezahat Gökyiğit Botanik Bahçesi ve Flora Araştırmaları Derneği Yayını İstanbul. 2012:47-83.

3. Gören N, Arda N, Çaliskan Z. Chemical characterization and biological activities of the genus Tanacetum (Compositae). Studies in Natural Products Chemistry. 2002;27:547-658.

4. Davis PH. Flora of Turkey and the East Aegean Islands. Vol. 3. Flora of Turkey and the East Aegean Islands Vol 3, 1970.

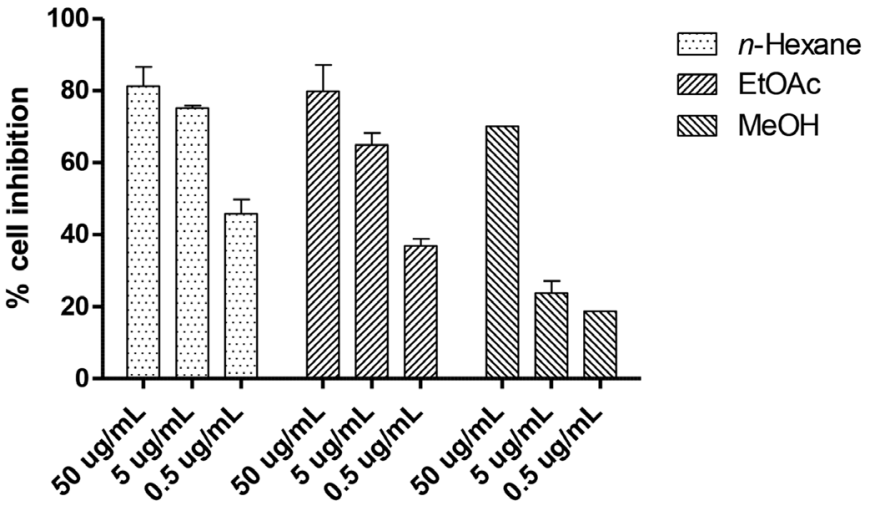

Figure 5. Various extracts of $T$. argenteum subsp. argenteum with different concentrations RAW264.7 cell line, iNOS method

5. Baytop T. Türkiyede bitkiler ile tedavi (geçmişte ve bugün). 1984;40.

6. Bruneton J, Pharmacognosy P. Medicinal plants. Pharmacognosy phytochemistry, 2003.

7. Gören N, Tahtasakal Ef, Pezzuto JM, Cordell GA, Shwarzt B, Prokscht P. Sesquiterpene lactones from Tanacetum argenteum. Phytochemistry. 1994;36:389-392.

8. Bagci E, Kocak A. Essential oil composition of two endemic Tanacetum (T. nitens (Boiss. \& Noe) Grierson and T. argenteum (Lam.) Willd. subsp. argenteum) (Asteraceae) taxa, growing wild in Turkey. Industrial crops and products. 2010;31:542-545.

9. Polatoğlu K, Demirci F, Demirci B, Gören N, Başer KH. Essential oil composition and antibacterial activity of Tanacetum argenteum (Lam.) Willd. ssp. argenteum and T. densum (Lab.) Schultz Bip. ssp. amani heywood from Turkey. J Oleo Sci. 2010;59:361-367.

10. Gören N, Tahtasakal E. Sesquiterpenoids from Tanacetum argenteum subsp. canum var. canum. Phytochemistry. 1997;45:107-109.

11. Orhan IE, Tosun F, Gülpınar AR, Kartal M, Duran A, Mihoglugil F, Akalgan D. LC-MS quantification of parthenolide and cholinesterase inhibitory potential of selected Tanacetum L. (Emend. Briq.) taxa. Phytochemistry Letters. 2015;11:347-352.

12. Goren N, Tahtasakal E, Krawiec M, Watson WH. Guaianolides from Tanacetum argenteum subsp. canum var. canum. J Nat Prod. 1998;61:560563.

13. Gören N, Tahtasakal E, Krawiec M, Watson WH. A guaianolide from Tanacetum argenteum subsp. flabellifolium. Phytochemistry. 1996;42:757760.

14. Quang DN, Harinantenaina L, Nishizawa T, Hashimoto T, Kohchi C, Soma G, Asakawa Y. Inhibition of nitric oxide production in RAW 264.7 cells by azaphilones from xylariaceous fungi. Biol Pharm Bull. 2006;29:34-37. 
15. Rateb ME, El-Gendy A-NA, El-Hawary SS, El-Shamy AM. Phytochemical and biological investigation of Tanacetum parthenium (L.) cultivated in Egypt. Journal of Medicinal Plants Research. 2007;1:018-026.

16. Rosselli S, Bruno M, Raimondo FM, Spadaro V, Varol M, Koparal AT, Maggio A. Cytotoxic effect of eudesmanolides isolated from flowers of Tanacetum vulgare ssp. siculum. Molecules. 2012;17:8186-8195.

17. Yumrutas O, Oztuzcu S, Pehlivan M, Ozturk N, Poyraz IE, Iğci YZ, Cevik MO, Bozgeyik I, Aksoy AF, Bagıs H, Arslan A. Cell viability, antiproliferation and antioxidant activities of Sideritis syriaca, Tanacetum argenteum subsp. argenteum and Achillea aleppica subsp. zederbaueri on human breast cancer cell line (MCF-7). 2015;5:1-5.

18. Şen A, Bingöl Özakpınar Ö, Birteksöz Tan S, Kültür Ş, Uras F, Bitiş L. Biological activities of aerial parts extracts of endemic Tanacetum argenteum subsp. argenteum. Marmara Pharmaceutical Journal 2017;21:286-290.

19. Dey SSM, Giri B. Anti-inflammatory and Anti-tumor Activities of Parthenolide: An Update. J Chem Biol Ther. 2016;2:107.

20. Hegazy FME, Hamed AR, Mohamed TA, Debbab A, Nakamura S, Matsuda $H$, Paré PW. Anti-inflammatory sesquiterpenes from the medicinal herb Tanacetum sinaicum. RSC Advances. 2015;5:44895-44901.
21. Petrovic SD, Dobric S, Bokonjic D, Niketic M, García-Piñeres A, Merfort I. Evaluation of Tanacetum larvatum for an anti-inflammatory activity and for the protection against indomethacin-induced ulcerogenesis in rats. $J$ Ethnopharmacol. 2003;87:109-113.

22. Nasri S, Amin G, Azimi A. Antiinflammatory and Antinociceptive of Hydro Alcoholic Tanacetum balsamita L. Extract. World Academy of Science, Engineering and Technology, International Journal of Medical, Health, Biomedical, Bioengineering and Pharmaceutical Engineering. 2014;8:186-189.

23. Bukhari IA, Khan RA, Gilani AU, Shah AJ, Hussain J, Ahmad VU. The analgesic, anti-inflammatory and calcium antagonist potential of Tanacetum artemisioides. Arch Pharm Res. 2007;30:303-312.

24. Hehner SP, Hofmann TG, Dröge W, Schmitz ML. The antiinflammatory sesquiterpene lactone parthenolide inhibits NF-kappa B by targeting the I kappa B kinase complex. J Immunol. 1999;163:5617-5623.

25. Hehner SP, Heinrich M, Bork PM, Vogt M, Ratter F, Lehmann V, SchulzeOsthoff K, Dröge W, Schmitz ML. Sesquiterpene lactones specifically inhibit activation of NF-kappa B by preventing the degradation of I kappa B-alpha and I kappa B-beta. J Biol Chem. 1998;273:1288-1297.

26. López-Franco O, Hernández-Vargas P, Ortiz-Muñoz G, Sanjuán G, Suzuki Y, Ortega L, Blanco J, Egido J, Gómez-Guerrero C. Parthenolide modulates the NF-kappaB-mediated inflammatory responses in experimental atherosclerosis. Arterioscler Thromb Vasc Biol. 2006;26:1864-1870. 